\title{
Pengaruh Perubahan Leverage pada Manajemen Laba
}

\section{S. Agus Andy Surya Dharma1 Fakultas Ekonomi dan Bisnis Universitas Udayana, Indonesia Email: gusandi67@gmail.com}

\author{
Dewa Gede Wirama² \\ Fakultas Ekonomi dan Bisnis \\ Universitas Udayana, Indonesia
}

\begin{abstract}
ABSTRAK
Penelitian ini menganalisis pengaruh perubahan leverage pada manajemen laba. Perubahan leverage diukur dengan perubahan debt-to-equity ratio dari tahun sebelumnya, dan manajemen laba diidentifikasi berdasarkan akrual diskresioner yang diestimasi dengan menggunakan Modified Jones Model. Return to equity, net profit margin, ukuran perusahaan, return on assets, dan leverage digunakan sebagai variabel kontrol. Variabel tersebut diidentifikasi dari hasil-hasil penelitian sebelumnya. Populasi penelitian ini adalahseluruh perusahaan nonkeuangan yang terdaftar di Bursa Efek Indonesia sepanjang tahun 2018. Jumlah sampel ditentukan dengan menggunakan rumus Slovin, yang menghasilkan 225 perusahaan, yang selanjutnya dipilih dengan stratifikasi. Teknik analisis yang digunakan adalah analisis regresi berganda. Berlawanan dengan hipotesis, hasil analisis pada penelitian ini menemukan bahwa perubahan leverage mempunyai pengaruh negatif pada manajemen laba. Hal tersebut kemungkinan terjadi karena kelompok sampel yang memiliki leverage yang membaik dari tahun sebelumnya ternyata memiliki level leverage yang jauh lebih tinggi dari kelompok sampel yang memiliki leverage yang memburuk.
\end{abstract}

Kata Kunci: Teori Agensi; Manajemen Laba; Perubahan Leverage.

\section{The Effect of Leverage Change on Earnings Management}

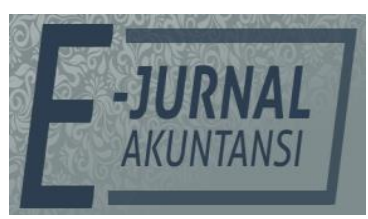

E-JA

e-Jurnal Akuntansi e-ISSN 2302-8556

Vol. 30 No. 6

Denpasar, Juni 2020

Hal.1344-1355

Artikel Masuk: 9 Januari 2020

Tanggal Diterima: 17 Maret 2020

\begin{abstract}
This research analyses the effect of changes in leverage on earnings management. Changes in leverage are changes in debt-to-equity ratio from previous years, and earnings management is measured by discretionary accruals estimated by the Modified Jones Model. Return to equity, net profit margin, companysize, return on assets, and the level of leverage are treated as control variables. They are identified from the results of previous researches. The research population is nonfinancial companies listed in the Bursa Efek Indonesia in 2018. Sample size is calculated using the Slovin Formula, resulted in 225 companies in the sample which is further randomly stratified. Data were analyzed by multiple regression technique. Contrary to the hypothesis, changes in leverage are negatively affect earnings management. The result was probably caused by the fact that companies with improving leverage have much higher level of leverage than companies with worsening leverage from the previous year.
\end{abstract}

ABSTRACT

Keywords: $\quad$ Agency Theory; Earnings Management; Leverage Change.

This Article is Avalilable in: $h t t p s: / / o j s . u n u d . a c . i d / i n d e x . p h p / A k u n t a n s i / i n d e x$ 


\section{PENDAHULUAN}

Manajemen laba merupakan topik yang banyak dibahas karena laba digunakan sebagai indikator dalam pengukuran kinerja perusahaan, yang selanjutnya dijadikan dasar pengambilan keputusan bisnis, terutama keputusan investasi. Perusahaan dengan laba yang meningkat dari satu periode ke periode lainya akan dianggap mampu berkinerja dengan baik. Menurut Siallagan \& Machfoedz (2006), informasi laba bisa menjadi indikator kegagalan dan keberhasilan dalam bisnis.

Manajemen laba adalah pilihan kebijakan akuntansi yang dilakukan untuk memengaruhi laba dalam rangka tujuan tertentu (Scott, 1997: 445). Menurut Merchant \& Rockness (1994), manajemen laba merupakan tindakan yang diambil pihak manajemen untuk memengaruhi laba yang akan dilaporkan. Penelitian yang dilakukan oleh Bassiouny (2016) menyatakan bahwa manajemen laba tidak informatif bagi pemegang saham karena dianggap sebagai tindakan oportunistik. Sebaliknya, Pramesti \& Budiasih (2017) menyatakan bahwa manajemen laba pada umumnya dilakukan untuk berbagai alasan yang baik untuk memenuhi kepentingan pemilik perusahaan seperti menaikkan nilai perusahaan.

Penelitian-penelitian sebelumnya telah banyak menguji tiga hipotesis dari teori akuntansi positif yang menjadi motivasi manajer melakukan manajemen laba. Penelitian manajemen laba seringkali berfokus pada hipotesis kedua yang menguji semakin tinggi rasio utang maka semakin tinggi kemungkinan manajer melakukan tindakan manajemen laba yang menaikkan laba. Salah satu penelitian tersebut adalah Mamu \& Dhamayanthi (2018) yang menyatakan terdapat hubungan positif antara leverage dan manajemen laba. Temuan serupa juga disampaikan oleh Partayadnya \& Suardikha (2018) yang menyatakan bahwa rasio leverage yang tinggi akan diikuti oleh kenaikan manajemen laba yang diukur dengan akrual diskresioner (discretionary accruals). Sari \& Astika (2015) dan Mahawyahrti \& Budiasih (2016) menyatakan bahwa perusahaan yang memiliki financial leverage tinggi melakukan manajemen laba karena perusahaan terancam default. Salleh \& Haat (2014) menyebutkan bahwa leverage menangkap kemungkinan pelanggaran kontrak utang karena semakin tinggi rasio leverage semakin besar risiko kontrak utang akan terlanggar.

Penelitian-penelitian sebelumnya tersebut mungkin kurang tepat jika dikaitkan dengan hipotesis kontrak utang dalam teori akuntansi positif yang menyebutkan bahwa manajer akan memilih metode akuntansi yang meningkatkan laba apabila kontrak utang akan terlanggar. Rasio utang yang tinggi belum dapat menunjukan perusahaan akan melanggar kontrak utang yang telah disepakati. Perusahaan yang rasio utangnya mengalami perubahan meningkat dari tahun-tahun sebelumnya akan lebih berpotensi mengalami default yaitu tidak bisa memenuhi kewajibanya untuk membayar utang pada waktunya, sehingga lebih mungkin melakukan manajemen laba yang menaikkan laba.

Perubahan leverage merupakan peningkatan atau penurunan rasio utang perusahaan yang dilihat dengan membandingkan debt to equity ratio (DER) tahun sekarang dengan tahun sebelumnya. Peningkatan DER dari tahun sebelumnya dapat menjadi pendorong manajer melakukan manajemen laba karena 
berpotensi meningkatkan potensi perusahaan mengalami default. Sweeney (1994) menyatakan bahwa perusahaan yang mendekati pelanggaran kontrak utang akan membuat perubahan akuntansi diskresioner untuk meningkatkan pendapatan. Pendapat sejalan juga dinyatakan oleh Othman \& Zeghal (2006).

Penelitian ini dilakukan pada seluruh perusahaan nonkeuangan yang terdaftar di Bursa Efek Indonesia pada tahun 2018. Alasan peneliti tidak memilih perusahaan sektor keuangan karena perusahaan pada sektor keuangan terkena berbagai regulasi yang berpengaruh pada struktur modalnya.

Jensen \& Meckling (1976) merumuskan bahwa perusahaan dapat dipandang sebagai "sekumpulan kontrak" (nexus of contracts), di mana satu atau lebih orang (prinsipal) memerintah orang lain (agen) untuk melakukan suatu jasa atas nama prinsipal. Prinsipal mempercayakan jasa manajemen dalam perusahaan kepada agen didasari oleh rasa percaya akan tanggungjawab (Lestari \& Wirawati, 2016). Teori agensi berasumsi bahwa agen memiliki lebih banyak informasi terkait kondisi perusahaan dibandingkan prinsipal, karena prinsipal tidak selalu bisa mengamati bagaimana kegiatan operasional perusahaan. Hal ini bisa menimbulkan kondisi yang disebut asimetri informasi yang memicu adanya suatu masalah yang disebut konflik keagenan, misalnya dalam bentuk manajemen laba yang oportunistik. Konflik tersebut akan menimbulkan biaya agensi yang harus dikeluarkan prinsipal untuk membatasi tindakan oportunistik oleh agen (Hill \& Jones, 1992).

Ada berbagai motivasi yang mendorong dilakukannya manajemen laba. Watts \& Zimmerman (1990) mengusulkan teori akuntansi positif dan menyatakan adanya tiga hipotesis manajemen laba yaitu: 1) Hipotesis Skema Bonus (Bonus Plan Hypothesis) menyatakan bahwa manajer pada perusahaan yang menerapkan skema bonus cenderung menggunakan metode akuntansi yang meningkatkan laba periode berjalan. 2) Hipotesis Kontrak Utang (Debt Covenant Hypothesis) menyatakan bahwa semakin dekat perusahaan dengan pelanggaran perjanjian utang maka semakin besar kemungkinan manajer menggunakan metode akuntansi yang meningkatkan laba periode berjalan. 3) Hipotesis Biaya Politik (Political Cost Hypothesis) menyatakan bahwa semakin tinggi biaya politik yang dihadapi perusahaan maka semakin besar kemungkinan manajer menggunakan metode akuntansi yang menurunkan laba periode berjalan.

Healy \& Wahlen (1999) menyatakan bahwa manajemen laba terjadi ketika manajer menerapkan kebijakan untuk membuat laporan keuangan terlihat lebih baik. Menurut Fischer \& Rosenzweig (1995), beberapa manajer memandang praktik manajemen laba sebagai alat manajerial yang sah untuk memaksimalkan return kepada pemegang saham. Pendapat serupa disebutkan oleh Pramesti \& Budiasih (2017) bahwa pada umumnya manajemen laba didasarkan pada alasan yang baik seperti menaikkan nilai perusahaan.

Menurut Scott (1997: 447), terdapat empat pola dalam manajemen laba berikut ini. 1) Taking a Bath. Pola ini umumnya terjadi ketika ada reorganisasi dan pengangkatan $\mathrm{CEO}$ baru. Pada pola ini, pengakuan beban dan kerugian periode mendatang dipercepat ke periode sekarang. Akibatnya laba pada periode sekarang sangat rendah dan pada periode berikutnya akan lebih tinggi dari seharusnya. 2) Income Minimization. Pola menurunkan laba ini dipilih oleh 
perusahaan yang memiliki eksposur politis yang tinggi selama periode profitabilitas tinggi. Kebijakan yang diambil dapat berupa pembebanan pengeluaran riset dan pengembangan yang cepat. 3) Income Maximization. Pola ini dilakukan pada saat laba menurun. Tindakan income maximization ini bertujuan untuk melaporkan laba yang tinggi untuk tujuan bonus yang lebih besar. Pola ini juga sering dilakukan oleh perusahaan yang terancam melakukan pelanggaran perjanjian utang. Kebijakan yang diambil dapat berupa melakukan meningkatkan produksi dan penjualan dengan mempertahankan biaya tetap yang sama. Akibatnya laba perusahaan akan meningkat. 4) Income Smoothing. Pola ini dilakukan perusahaan untuk meratakan laba yang dilaporkan sehingga dapat mengurangi fluktuasi laba. Pada umumnya investor lebih menyukai laba yang relatif stabil. Manajer dapat meratakan laba yang dilaporkan dari waktu ke waktu untuk menerima kompensasi yang relatif konstan. Kebijakan yang diambil perusahaan dapat berupa peningkatan atau penurunan laba sesuai dengan kondisi perusahaan saat itu.

Perubahan leverage dapat dijadikan penduga perilaku manajer apakah akan melakukan tindakan peningkatan laba atau tidak. Perusahaan dengan tingkat utang yang meningkat dari tahun-tahun sebelumnya bisa menjadi pendorong manajer melakukan manajemen laba karena berpotensi mengalami pelanggaran kontrak utang. Beneish \& Press dalam Herawati (2007) menyatakan bahwa pelanggaran perjanjian utang akan menyebabkan perusahaan terkena berbagai penalti keuangan.

Hipotesis kontrak utang dalam teori akuntansi positif menyebutkan bahwa manajer akan memilih metode akuntansi untuk meningkatkan laba apabila kontrak utang akan terlanggar (Watts \& Zimmerman, 1990). Perusahaan dengan rasio leverage yang memburuk dari tahun sebelumnya lebih berpotensi tidak dapat memenuhi kewajibanya pada saat jatuh tempo dan berakhir dengan terlanggarnya kontrak utang. Menurut Kalay (1982), semakin tinggi rasio utang semakin dekat perusahaan pada kendala dalam perjanjian utang. Manajer akan terdorong untuk melakukan praktik manajemen laba yang menaikkan laba untuk mengurangi kemungkinan pelanggaran kontrak utang dan meningkatkan posisi tawar perusahaan dalam renegosiasi utang. Perusahaan dalam kondisi rasio utang yang meningkat selain berpotensi gagal bayar pada saat jatuh tempo juga berisiko kehilangan kepercayaan oleh investor. Menurut Yanti \& Setiawan (2019) investor akan lebih memilih perusahaan yang memiliki tingkat utang yang lebih rendah. Hal ini disebabkan tingginya risiko yang mungkin akan dihadapi perusahaan seperti percepatan jatuh tempo utang dan peningkatan dalam tingkat bunga. Gul et al. (2000) menunjukkan bahwa hubungan pendapatan pada return dipengaruhi secara negatif oleh utang.

Hubungan kontrak yang terjadi antara agen dan prinsipal dapat mendorong manajer selaku agen untuk melakukan manajemen laba guna memenuhi keinginan prinsipal. Bosse \& Phillips (2014) dalam penelitianya menyatakan prinsipal mengharapkan agen untuk menghasilkan pencapaian sejumlah nilai tertentu di masa depan. Manajemen akan mengelola laba untuk menghindari pelaporan kerugian (Ghazali et al., 2015). Pengguna laporan keuangan akan berharap terdapat peningkatan laba pada perusahaan. Sangat 
penting bagi agen untuk bisa mempertahankan kepercayaan prinsipal untuk tetap menanamkan modalnya pada perusahaan.

Penelitian yang dilakukan oleh Mahawyahrti \& Budiasih (2016), Pramesti \& Budiasih (2017), dan Sari \& Astika (2015) menunjukkan bahwa leverage berpengaruh positif pada Income Increasing Earnings Management. Berdasarkan uraian tersebut, maka dapat dirumuskan hipotesis sebagai berikut.

$\mathrm{H}_{1}$ : Perubahan leverage berpengaruh positif pada manajemen laba

\section{METODE PENELITIAN}

Penelitian ini dilakukan pada seluruh perusahaan nonkeuangan yang terdaftar di Bursa Efek Indonesia pada tahun 2018. Laporan keuangan yang diakses dari www.idx.co.id. Manajemen laba menggunakan proksi akrual diskresioner yang diestimasi dengan menggunakan Modified Jones Model (Dechow et al., 1995). Model ini lebih baik dibanding model Jones standar dalam mengukur kasus manipulasi pendapatan. Model perhitunganya adalah sebagai berikut.

\section{TACit $=$ NIit - CFOit}

Kemudian menghitung nilai total accrual (TAC) yang diestimasi dengan persamaan regresi untuk menentukan koefisien dalam persamaan.

$$
\frac{\text { TACit }}{\text { TAit }}-1=\alpha 1\left(\frac{1}{\text { TAit }}-1\right)+\alpha 2\left(\frac{a \text { REVit- } \Delta R E C i t}{\text { TAit }}-1\right)+\alpha 3\left(\frac{\text { pPEit }}{\text { TAit }}-1\right)+\varepsilon_{\ldots . .} .
$$

Dengan menggunakan koefisien regresi tersebut maka dapat dihitung nilai nondiscretionary accrual (NDTA) dengan rumus sebagai berikut.

$$
\text { NDTAC }=\alpha 1 \frac{1}{\text { TAit }-1}+\alpha 2 \frac{(\Delta \text { REVit- } \Delta \text { RECit })}{\text { TAit }-1}+\alpha 3 \frac{\text { PPEit }}{\text { TAit }-1}+\varepsilon
$$

Discretionary accrual (DTA) merupakan residual yang diperoleh dari estimasi total accrual yang dihitung sebagai berikut:

$$
\text { DTAC }=(\text { TACit } / \text { TAit }-1)-\text { NDTACit }
$$

Keterangan:

DTACit = Discretionary accrual perusahaan i pada periode $\mathrm{t}$

NDTACit $=$ Non Discretionary accrual perusahaan $\mathrm{i}$ pada periode $\mathrm{t}$

NIit $\quad=$ Net income perusahaan i pada periode $\mathrm{t}$

TACit $\quad=$ Total accrual perusahaan i pada periode $\mathrm{t}$

CFOit $=$ Aliran arus kas operasi perusahaan i pada periode $\mathrm{t}$

TAit-1 = Total aktiva perusahaan i pada periode $\mathrm{t}-1$

$\triangle$ REVit $\quad=$ Perubahan penjualan perusahaan $\mathrm{i}$ pada periode $\mathrm{t}$

PPEit $\quad=$ Aktiva tetap perusahaan $\mathrm{i}$ pada periode $\mathrm{t}$

$\triangle$ RECit $\quad=$ Perubahan piutang perusahaan $\mathrm{i}$ pada periode $\mathrm{t}$

Perubahan leverage diukur dengan membandingkan Debt to Equity Ratio (DER) tahun sekarang dengan tahun sebelumnya pada laporan keuangan.

$$
\mathrm{DER}=\frac{\text { Utang }}{\text { Modal }}
$$

Kemudian menghitung perubahan leverage meningkat atau menurun menggunakan rumus sebagai berikut.

Perubahan Leverage $=\frac{\text { DERt-DERt-1 }}{\text { DERt }-1}$

Keterangan : 


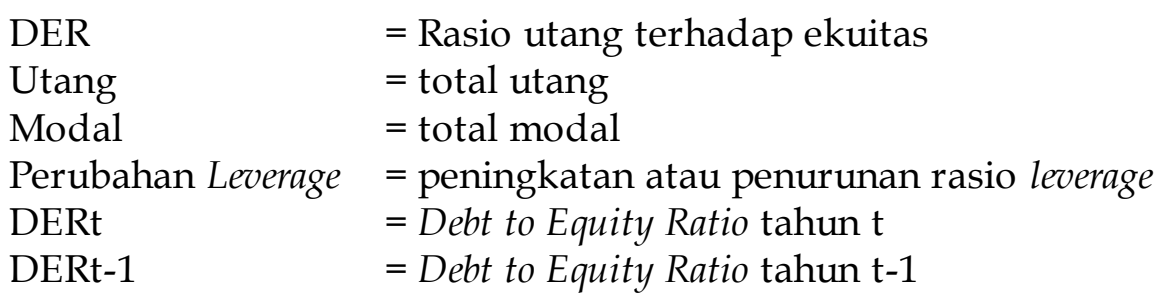

Variabel kontrol dalam penelitian ini adalah return on equity (ROE), net profit margin (NPM), ukuran perusahaan, return on assets (ROA), dan leverage. ROE adalah rasio untuk mengukur profitabilitas, yang dihitung dengan membagi laba bersih dengan total ekuitas. NPM adalah rasio antara laba bersih dengan penjualan bersih, yang menunjukkan marjin dari setiap penjualan terhadap seluruh biaya yang diperhitungkan perusahaan. Ukuran perusahaan mencerminkan besar atau kecilnya suatu perusahaan, diukur dengan logaritma natural dari total aset. Seperti ROE, ROA adalah rasio untuk mengukur profitabilitas. ROA dihitung dengan membagi laba bersih dengan total aset. Leverage adalah rasio yang mencerminkan kemampuan perusahaan memenuhi kewajibanya. Leverage dihitung dengan membagi total utang dengan total modal. Populasi pada penelitian ini adalah seluruh perusahaan nonkeuangan yang terdaftar di Bursa Efek Indonesia sepanjang tahun 2018. Perusahaan sektor keuangan tidak dipilih dalam penelitian ini karena terkena berbagai regulasi yang berpengaruh pada struktur modalnya. Pengambilan sampel pada penelitian ini menggunakan teknik stratified random sampling yaitu suatu teknik pengambilan sampel dengan memperhatikan suatu tingkatan (strata) pada elemen populasi. Rumus Slovin digunakan untuk menentukan jumlah sampel yang selanjutnya dipilih dengan stratified random sampling.

Teknik analisis yang digunakan dalam penelitian ini adalah analisis regresi berganda. Sebelum melakukan pengujian hipotesis, terlebih dahulu dilakukan uji asumsi klasik. Persamaan regresi tersebut adalah sebagai berikut:

$$
Y=\alpha+\beta_{1} X_{1}+\beta_{2} X_{2}+\beta_{3} X_{3}+\beta_{4} X_{4}+\beta_{5} X_{5}+\beta_{6} X_{6}+\varepsilon
$$

Keterangan:

$$
\begin{array}{ll}
\mathrm{Y} & =\text { Manajemen laba } \\
\mathrm{a} & =\text { Konstanta } \\
\beta & =\text { Koefisien regresi } \\
\mathrm{e} & =\text { Standar error } \\
\mathrm{X}_{1} & =\text { Perubahan leverage } \\
\mathrm{X}_{2} & =\text { ROA } \\
\mathrm{X}_{3} & =\mathrm{NPM} \\
\mathrm{X}_{4} & =\text { Ukuran perusahaan } \\
\mathrm{X}_{5} & =\text { ROA } \\
\mathrm{X}_{6} & =\text { Leverage }
\end{array}
$$

\section{HASIL DAN PEMBAHASAN}

Uji normalitas bertujuan untuk menguji apakah data dalam model regresi berdistribusi normal atau tidak. Namun, Central Limit Theorem menyatakan bahwa jika jumlah observasi cukup besar ( $\mathrm{n}>30$ ) maka data dapat diasumsi berdistribusi normal dan pengujian normalitas dapat diabaikan (Gujarati, 
2003:138). Sampel dalam penelitian ini berjumlah 225, dan oleh karena itu maka asumsi normalitas dianggap terpenuhi.

Uji multikolinieritas bertujuan untuk menguji apakah ada korelasi antar variabel bebas dalam model regresi. Indikasi untuk mengetahui adanya kolerasi tersebut dapat dilihat dari nilai tolerance dan nilai variance inflation factor (VIF). Berdasarkan hasil uji pada Tabel 1. dapat dilihat nilai tolerance pada masingmasing variabel lebih besar dari 0,1 dan nilai VIF kurang dari 10. Nilai tersebut menunjukkan model regresi bebas dari masalah multikoleniaritas.

\section{Tabel 1. Hasil Uji Multikoleniaritas}

\begin{tabular}{lll}
\hline \multirow{2}{*}{ Variabel } & \multicolumn{2}{l}{ Collinearity Statistics } \\
\cline { 2 - 3 } & Tolerance & VIF \\
\hline (Constant) & 0,825 & 1,213 \\
Perubahan Leverage & 0,714 & 1,400 \\
ROE & 0,994 & 1,006 \\
NPM & 0,955 & 1,047 \\
Ukuran Perusahaan & 0,614 & 1,628 \\
ROA & 0,946 & 1,057 \\
Leverage &
\end{tabular}

Sumber: Data Penelitian, 2019

Uji heteroskedastisitas bertujuan untuk menguji apakah dalam model regresi terjadi ketidaksamaan varians dari residual satu amatan ke amatan lain. Mendeteksi ada atau tidaknya masalah heteroskedastisitas menggunakan Uji Glejser. Pengujian dilakukan dengan cara meregresi variabel independen terhadap absolute residual model regresi yang digunakan. Apabila nilai signifikansi variabel independen lebih dari 0,05 maka dapat disimpulkan tidak terjadi gejala heteroskedastisitas.

Tabel 2. Hasil Uji Heteroskedastisitas

\begin{tabular}{lll}
\hline Variabel & T & Sig. \\
\hline (Constant) & 1,972 & 0,050 \\
Perubahan Leverage & $-1,795$ & 0,074 \\
ROE & $-0,645$ & 0,520 \\
NPM & $-1,151$ & 0,251 \\
Ukuran Perusahaan & 0,922 & 0,358 \\
ROA & 0,453 & 0,651 \\
Leverage & $-0,234$ & 0,815
\end{tabular}

Sumber: Data Penelitian, 2019

Berdasarkan hasil uji pada Tabel 2. dapat dilihat nilai signifikansi dari variabel Perubahan Leverage, ROE, NPM, Ukuran Perusahaan, ROA, dan Leverage lebih besar dari 0,05. Dengan demikian, model yang dibuat dalam penelitian ini tidak mengandung masalah heteroskedastisitas.

Setelah dilakukan uji asumsi klasik dilakukan statistik deskriptif untuk mengetahui gambaran umum dari masing-masing variabel yang diteliti meliputi nilai minimum, maksimum, rata-rata dan standar deviasinya. Statistik deskriptif disajikan dalam Tabel 3. 
DHARMA, S.A.A.S. \& WIRAMA, D.G.

Tabel 3. Statistik Deskriptif

\begin{tabular}{llllll}
\hline & N & Minimum & \multicolumn{2}{l}{ Maksimum Rata-rata } & Deviasi Standar \\
\hline Perubahan Leverage & 225 & $-0,89$ & 2,79 & 0,03 & 0,39 \\
ROE & 225 & $-13300,37$ & 10687,42 & 99,30 & 1463,68 \\
NPM & 225 & $-1,69$ & 450,81 & 2,02 & 30,05 \\
Ukuran Perusahaan & 225 & 12,24 & 32,38 & 25,57 & 4,79 \\
ROA & 225 & $-0,34$ & 0,47 & 0,02 & 0,08 \\
Leverage & 225 & 0,00 & 19,30 & 1,33 & 2,02 \\
Manajemen Laba & 225 & $-0,35$ & 0,72 & 0,04 & 0,12 \\
Valid N (listwise) & 225 & & & & \\
\hline
\end{tabular}

Sumber: Data Penelitian, 2019

Perubahan leverage memiliki nilai minimum sebesar $-0,89$ dan nilai maksimum sebesar 2,79. Nilai rata-rata perubahan leverage pada perusahaan dalam sampel penelitian sebesar 0,03 lebih kecil dari nilai deviasi standarnya sebesar 0,39, yang menunjukan adanya variasi data yang besar. Kondisi yang sama terjadi pada variabel lain, yaitu ROE, NPM, ukuran perusahaan, ROA, dan leverage.

Manajemen laba memiliki nilai minimum sebesar $-0,35$ dan nilai maksimum sebesar 0,72. Nilai rata-rata manajemen laba pada perusahaan dalam sampel penelitian sebesar 0,04 lebih kecil dari nilai deviasi standarnya sebesar 0,12 , yang juga mengindikasikan adanya variasi data yang besar.

Tabel 4. menyajikan nilai koefisien determinasi (adjusted $\mathrm{R}^{2}$ ) sebesar 0,116. Nilai sebesar 0,116 menunjukkan manajemen laba (Y) dapat dijelaskan oleh variabel Perubahan Leverage, ROE, NPM, ukuran perusahaan, ROA, dan leverage sebesar 11,6 persen sedangkan sisanya sebesar 88,4 persen dijelaskan oleh faktor lain di luar persamaan regresi.

Tabel 4. Hasil Koefisien Determinasi

\begin{tabular}{|c|c|c|c|c|}
\hline$\overline{\text { Model }}$ & $\bar{R}$ & R Square & Adjusted R Square & Std. Error of the Estimate \\
\hline & 0,373 & 0,139 & 0,116 & 0,117 \\
\hline
\end{tabular}

Sumber: Data Penelitian, 2019

Tabel 5. menunjukkan nilai F-hitung sebesar 5,890 dengan tingkat signifikansi sebesar 0,000. Nilai signifikansi yang lebih lebih kecil 0,005 mempunyai bahwa arti model dalam penelitian ini mampu menjelaskan variabel manajemen laba.

Tabel 5. Hasil Uji Kelayakan Model

\begin{tabular}{llll}
\hline Model & F & Sig. \\
\hline & $\begin{array}{l}\text { Regression } \\
\text { Residual } \\
\text { Total }\end{array}$ & 5,890 & 0,000 \\
& & \\
\hline
\end{tabular}

Sumber: Data Penelitian, 2019

Setelah uji kelayakan model dilakukan analisis regresi berganda untuk mengetahui bagaimana pengaruh masing-masing variabel bebas pada variabel terikat, apabila tingkat signifikansinya diatas 0,05 maka dapat dikatakan tidak ada pengaruh antara variabel bebas dengan variabel terikat, sebaliknya apabila tingkat signifikansinya lebih kecil atau sama dengan 0,005 berarti ada pengaruh. Adapun hasil dari analisis regresi berganda dilihat dari Tabel 6. 
Tabel 6. Hasil Regresi Linier Berganda

\begin{tabular}{|c|c|c|c|c|}
\hline \multirow{2}{*}{ Model } & \multicolumn{2}{|c|}{$\begin{array}{l}\text { Unstandardized } \\
\text { Coefficients }\end{array}$} & \multirow{2}{*}{$\mathrm{t}$} & \multirow{2}{*}{ Sig. } \\
\hline & B & Std. Error & & \\
\hline (Constant) & 0,00500 & 0,044 & 0,120 & 0,905 \\
\hline Perubahan Leverage & $-0,04400$ & 0,022 & $-1,969$ & 0,050 \\
\hline $\mathrm{ROE}$ & $-0,00001$ & 0,000 & $-2,065$ & 0,040 \\
\hline NPM & 0,00006 & 0,000 & 0,229 & 0,819 \\
\hline Ukuran Perusahaan & 0,00100 & 0,002 & 0,716 & 0,475 \\
\hline $\mathrm{ROA}$ & 0,51400 & 0,120 & 4,289 & 0,000 \\
\hline Leverage & $-0,00100$ & 0,004 & $-0,339$ & 0,735 \\
\hline
\end{tabular}

Sumber: Data Penelitian, 2019

Berdasarkan hasil uji regresi yang disajikan pada Tabel 6. perubahan leverage memiliki nilai koefisien sebesar -0,04400 dan nilai t-hitung sebesar -1,969 dengan signifikansi sebesar 0,050. Hal ini menunjukan adanya hubungan signifikan perubahan leverage pada manajemen laba dengan koefisien regresi yang negatif, dan dengan demikian hipotesis pada penelitian ini ditolak.

Hasil penelitian ini berbanding terbalik dengan hipotesis penelitian yang menyatakan perubahan leverage berpengaruh positif pada manajemen laba yang dirumuskan berdasarkan hipotesis kontrak utang dalam teori akuntansi positif oleh Watts \& Zimmerman (1990) dan teori agensi oleh Jensen \& Meckling (1976) serta penelitian dari Mahawyahrti \& Budiasih (2016), Pramesti \& Budiasih (2017), dan Sari \& Astika (2015). Perubahan leverage berpengaruh negatif pada manajemen laba kemungkinan disebabkan karena kelompok leverage tahun 2017 pada kelompok perubahan leverage yang membaik jauh lebih tinggi dibandingkan kelompok sampel dengan perubahan leverage yang memburuk. Penelitian ini membuktikan leverage yang meningkat dari tahun sebelumnya tidak menyebabkan manajemen meningkatkan manajemen laba. Sebaliknya leverage yang menurun dapat tetap mendorong manajer melakukan manajemen laba.

Berdasarkan hasil uji regresi pada Tabel 6. ROE memiliki nilai koefisien sebesar -0,00001 dan nilai t-hitung sebesar -2,065 dengan signifikansi sebesar 0,040. Hal ini menunjukan adanya hubungan signifikan ROE pada manajemen laba. Penelitian ini tidak sejalan dengan penelitian yang dilakukan Gunawan et al., (2015) yang menyatakan ROE tidak berpengaruh pada manajemen laba. NPM memiliki nilai koefisien sebesar 0,00006 dan nilai t-hitung sebesar 0,229 dengan signifikansi sebesar 0,819. Hal ini menunjukan tidak ada hubungan signifikan NPM pada manajemen laba. Hasil pada penelitian ini tidak sejalan dengan Nahar \& Erawati (2017) yang menyatakan NPM berpengaruh negatif pada manajemen laba. Ukuran perusahaan memiliki nilai koefisien sebesar 0,00100 dan nilai t-hitung sebesar 0,716 dengan signifikansi sebesar 0,475. Hal ini menunjukan tidak ada hubungan signifikan ukuran perusahaan pada manajemen laba. Hasil penelitian ini sejalan dengan Astuti et al., (2017) dan Agustia \& Suryani (2018) yang menyatakan ukuran perusahaan tidak berpengaruh pada manajemen laba. ROA memiliki nilai koefisien sebesar 0,51400 
dan nilai t-hitung sebesar 4,289 dengan signifikansi sebesar 0,000. Hal ini menunjukan adanya hubungan signifikan ROA pada manajemen laba dengan koefisien regresi yang positif. Hasil pada penelitian ini sejalan dengan penelitian yang dilakukan Yanti \& Setiawan (2019) dan Amertha (2013) menyatakan bahwa ROA berpengaruh positif pada manajemen laba. Leverage memiliki nilai koefisien sebesar -0,00100 dan nilai t-hitung sebesar -0,339 dengan signifikansi sebesar 0,735 . Hal ini menunjukan tidak ada hubungan signifikan leverage pada manajemen laba. Hasil penelitian ini tidak sejalan dengan penelitian Pramesti \& Budiasih (2017) dan Partayadnya \& Suardikha (2018) yang menyatakan leverage berpengaruh positif pada manajemen laba.

Hasil penelitian ini memberikan gambaran mengenai interaksi manajemen laba dengan perubahan leverage pada perusahaaan nonkeuangan yang terdaftar di Bursa Efek Indonesia. Perubahan leverage mempunyai hubungan yang negatif dengan manajemen laba jika dilihat dari hasil penelitian ini, artinya apabila perubahan leverage meningkat maka manajemen laba akan menurun. Penelitian ini diharapkan memberikan kontribusi bagi stakeholder yang memerlukan bahan pertimbangan bagi keputusan bisnisnya, maupun peneliti lain di masa yang akan datang.

\section{SIMPULAN}

Berdasarkan hasil analisis data dapat diambil kesimpulan bahwa perubahan leverage berpengaruh negatif pada manajemen laba. Peningkatan leverage diikuti dengan penurunan kecenderungan melakukan manajemen laba. Temuan ini berlawanan dengan hipotesis dan dapat dikaji lebih lanjut oleh peneliti berikutnya.

Bagi para stakeholder disarankan untuk tidak hanya memperhatikan level leverage seperti yang disarankan pada penelitian-penelitian terdahulu, namun juga perubahannya. Penelitian selanjutnya dapat menambahkan variabel lain sebagai penduga manajemen laba karena ajusted $R^{2}$ pada penelitian ini masih tergolong rendah yaitu sebesar 11,6 persen. Hal tersebut mengindikasikan adanya banyak variabel lain yang tidak diperhitungkan dalam penelitian ini.

\section{REFERENSI}

Agustia, Y. P., \& Suryani, E. (2018). Pengaruh Ukuran Perusahaan, Umur Perusahaan, Leverage, Dan Profitabilitas Terhadap Manajemen Laba (Studi Pada Perusahaan Pertambangan yang Terdaftar di Bursa Efek Indonesia Periode 2014-2016). Jurnal ASET, 10(1), 63-74. https://doi.org/10.17509/jaset.v10i1.12571

Amertha, I. S. P. (2013). Pengaruh Return on Asset Pada Praktik Manajemen Laba Dengan Moderasi Corporate Governance. E-Jurnal Akuntansi, 4(2), 373387.

Astuti, A. Y., Nuraina, E., \& Wijaya, A. L. (2017). Pengaruh Ukuran Perusahaan Dan Leverage Terhadap Manajemen Laba. Forum Ilmiah Pendidikan Akuntansi, 5(1), 501-514.

Bassiouny, S. W. (2016). The Impact Of Firm Characteristics On Earnings Management: An Empirical Study On The Listed Firms In Egypt. The Business and Management Review, 7(2), 91-101. 
Bosse, D. A., \& Phillips, R. A. (2014). Agency Theory and Bounded Self-Interest. Academy of Management Review, 1-56. https://doi.org/10.5465/amr.2013.0420

Dechow, P. M., Sloan, R. G., \& Sweeney, A. P. (1995). Detecting Earnings Management. The Accounting Review, 70(2), 193-225.

Fischer, M. ., \& Rosenzweig, K. (1995). Attitudes of Students and Accounting Practitioners Concerning the Ethical Acceptability of Earnings Management. Journal of Business Ethics, 14, 433-444.

Ghazali, A. W., Shafie, N. A., \& Sanusi, Z. M. (2015). Earnings Management: An Analysis of Opportunistic Behaviour, Monitoring Mechanism and Financial Distress. Procedia Economics and Finance, 28(April), 190-201. https://doi.org/10.1016/s2212-5671(15)01100-4

Gujarati, D. N. (2003). Basic Econometrics (Fourth Edi; A. Bright, ed.). New York: Gary Burke.

Gul, F. A., Leung, S., \& Srinidhi, B. (2000). The Effect of Investment Opportunity Set and Debt Level on Earnings-Returns Relationship and the Pricing of Discretionary Accruals. SSRN Electronic Journal, (July), 1-36. https://doi.org/10.2139/ssrn.236080

Gunawan, I. K., Darmawan, N. A. S., \& Purnamawati, I. G. A. (2015). Pengaruh Ukuran Perusahaan, Profitabilitas, dan Leverage Terhadap Manajemen Laba. E-Journal S1 Ak Universitas Pendidikan Ganesha, 03(1).

Healy, P. M., \& Wahlen, J. M. (1999). A Review of the Earnings Management Literature and Its Implications for Standard Setting. Accounting Horizons, 13(4), 365-383. https://doi.org/10.2308/acch.1999.13.4.365

Herawati, N. (2007). Manajemen Laba Pada Perusahaan Yang Melanggar Perjanjian Utang. EKUITAS (Jurnal Ekonomi Dan Keuangan), 14(1), 97-113. https://doi.org/10.24034/j25485024.y2010.v14.i1.2121

Hill, C. W., \& Jones, T. M. (1992). Stakeholder-Agency Theory Charles. Journal of Management Studies, 29(2), 131-154.

Jensen, M. C., \& Meckling, W. H. (1976). Theory of The Firm: Manajerial Behavior, Ageny Cost and Ownership structure. Journal of Financial Economics, 3, 305-360.

Kalay, A. (1982). Stockholder-Bondholder Conflict and Dividend Constraints. Journal of Financial Economics, 10(2), 211-233. https://doi.org/10.1016/0304-405X(82)90014-9

Lestari, S. D., \& Wirawati, N. G. P. (2016). Good Corporate Governance Sebagai Pemoderasi Pengaruh Asimetri Informasi Pada Manajemen Laba. E-Jurnal Akuntansi Universitas Udayana, 16(1), 156-182. https://doi.org/10.32477/jkb.v26i1.265

Mahawyahrti, P. T., \& Budiasih, I. G. A. N. (2016). Asimetri Informasi, Leverage, dan Ukuran Perusahaan Pada Manajemen Laba. Jurnal Ilmiah Akuntansi Dan Bisnis, 11(2), 100-110.

Mamu, Y. T. L., \& Dhamayanthi, I. G. A. E. (2018). Moderasi Kualitas Auditor Terhadap Pengaruh Leverage , Kepemilikan Manajerial , dan Kepemilikan Institusional Pada Manajemen Laba. E-Jurnal Akuntansi Universitas Udayana, 25, 272-299. 
Merchant, K. A., \& Rockness, J. (1994). The Ethics of Managing Earnings: An Empirical Investigation. Journal of Accounting and Public Policy, 13(1), 7994. https://doi.org/10.1016/0278-4254(94)90013-2

Nahar, M., \& Erawati, T. (2017). Pengaruh NPM, FDR, Komite Audit, Pertumbuhan Usaha, Leverage, Dan Size Terhadap Manajemen Laba. Akuntansi Dewantara, 1(1), 63-74.

Othman, H. Ben, \& Zeghal, D. (2006). A study of earnings-management motives in the Anglo-American and Euro-Continental accounting models: The Canadian and French cases. International Journal of Accounting, 41(4), 406435. https://doi.org/10.1016/j.intacc.2006.09.004

Partayadnya, I. M. A., \& Suardikha, I. M. S. (2018). Pengaruh Mekanisme GCG, Kualitas Audit, dan Leverage Terhadap Manajemen Laba pada Perusahaan Manufaktur di BEI. E-Jurnal Akuntansi Universitas Udayana, Vol. 25(No. 1), 31-53.

Pramesti, I. A. J., \& Budiasih, I. G. A. N. (2017). Pengaruh Asimetri Informasi, Leverage, dan Kepemilikan Manajerial Pada Manajemen Laba. E-Jurnal Akuntansi Universitas Udayana, 21(1), 200-226.

Salleh, N. M. Z. N., \& Haat, M. H. C. (2014). Audit Committee and Earnings Management: Pre and Post MCCG. International Review of Management and Business Research, 3(1), 307-318.

Sari, P., \& Astika, P. (2015). Moderasi Good Corporate Governance pada pengaruh Antara Leverage dan Manajemen laba. E-Jurnal Akuntansi Universitas Udayana, 12(3), 752-769.

Scott, W. R. (1997). Fnancial Accounting Theory (Seventh Ed). Pearson: Toronto.

Siallagan, H., \& Machfoedz, M. (2006). Mekanisme Corporate Governance, Kualitas Laba dan Nilai Perusahaan. Simposium Nasional Akuntansi, 23-26.

Sweeney, A. P. (1994). Debt-covenant violations and managers' accounting responses. Jounal of Accounting and Economics, 17, 281-308.

Watts, R. L., \& Zimmerman, J. L. (1990). Positive Accounting Theory: A Ten Year Perspective. The Accounting Review, 65(1), 131-156.

Yanti, N. P. T. R., \& Setiawan, P. E. (2019). Pengaruh Asimetri Informasi, Ukuran Perusahaan, Leverage dan Profitabilitas pada Manajemen Laba. E-Jurnal Akuntansi Universitas Udayana, 27(1), 708-736. 